\title{
Hydro-Biogeochemical Approaches to Understanding of Water and Carbon Cycling in the Gwangneung Forest Catchment
}

\author{
Su-Jin Kim ${ }^{1}$, Dongho Lee ${ }^{1}$, Joon Kim ${ }^{1 *}$, and Sung Kim ${ }^{2}$ \\ ${ }^{1}$ Department of Atmospheric Sciences/Global Environmental Laboratory, Yonsei University, \\ Shinchon-dong 134, Seodaemun-gu, Seoul 120-749, Korea \\ ${ }^{2}$ Sustainable Water Resources Research Center/KICT, Goyang City, Kyeonggi-do 411-712, Korea \\ (Received March 12, 2007; Accepted June 11, 2007)
}

\author{
김수진 $^{1} \cdot$ 이동호 $^{1} \cdot$ 김 준 $^{*} \cdot$ 김 승 $^{2}$ \\ 1연세대학교 대기과학과/지구환경연구소, \\ 2건설기술연구원/수자원의 지속적 확보기술개발 사업단 \\ (2007년 3월 12일 접수; 2007년 6월 11일 수락)
}

수문생지화학적 접근을 통한 광릉 산림 유역의 물과 탄소 순환 이해

\begin{abstract}
The information on flowpath, storage, residence time, and interactions of water and carbon transport in a catchment is the prerequisite to the understanding and predicting of water and carbon cycling in the mountainous landscapes of Korea. In this paper, along with some up-to-date results, we present the principal methods that are currently used in HydroKorea and CarboKorea research to obtain such information. Various catchment hydrological processes have been examined on the basis of the water table fluctuations, the end-member mixing model, the cross correlation analysis, and cosmogenic radioactive isotope activity. In the Gwangneung catchment, the contribution of surface discharge was relatively large, and the changes in the amount, intensity and patterns of precipitation affected both the flowpath and the mean residence time of water. Particularly during the summer monsoon, changes in precipitation patterns and hydrological processes in the catchment influenced the carbon cycle such that the persistent precipitation increased the discharge of dissolved organic carbon (DOC) concentrated in the surface soil layer. The improved understanding of the hydrological processes presented in this report will enable a more realistic assessment of the effects of climate changes on the water resource management and on the carbon cycling in forest catchments.
\end{abstract}

Key words : Gwangneung forest catchment, Hydro-biogeochemistry, Monsoon, Carbon and water cycling, DOC

\section{INTRODUCTION}

The water and carbon cycles in forest catchments are important elements for understanding the impact of global environmental changes on terrestrial ecosystems. Various theories have been suggested to better understand water discharge (Horton, 1933; Betson, 1964; Kirkby, 1978; Anderson and Burt, 1991; Kim et al., 2003) and its effect on carbon efflux processes

Corresponding Author: Joon Kim(joon-kim@yonsei.ac.kr) from forest catchments (McGlynn and McDonnell, 2003; Kawasaki et al., 2005; Schulze, 2006). Most of the results indicated that the hydrological flowpaths are important in carbon dynamics within the forest catchments. In Korea, more than $50 \%$ of the annual precipitation falls in the summer monsoon season, which quickly discharges to the ocean due to the steep slopes and short river lengths $(<500 \mathrm{~km})$. Therefore, the water regime in the catchment undergoes drastic changes 
Table 1. Global carbon flux to oceans

\begin{tabular}{ccc}
\hline \hline & Flux $\left(\right.$ Gt-C yr $\left.{ }^{-1}\right)$ & Reference \\
\hline DOC & 0.20 & Meybeck 1980 \\
DIC & 0.24 & Meybeck 1980 \\
POC & 0.10 & Meybeck 1980 \\
DOC & 0.21 & Ludwig et al. 1996 \\
POC & 0.17 & Ludwig et al. 1996 \\
TOC & 0.41 & Schlesinger and Melack 1981
\end{tabular}

DOC : Dissolved Organic Carbon DIC : Dissolved Inorganic Carbon

POC : Particulate Organic Carbon TOC : Total Organic Carbon

with recurring wet and dry seasons, which makes it difficult to interpret and predict hydrological processes and subsequently their effect on carbon cycling.

The transport of terrestrial carbon into streams, rivers and eventually the oceans is an important link between terrestrial and oceanic carbon cycles (Ludwig et al., 1996; Warnken and Santschi, 2004). As compared to the terrestrial carbon sinks (1.9 Gt-C/yr; Prentice et al., 2001), the organic carbon transport from terrestrial ecosystems to oceans is $0.4 \mathrm{Gt}-\mathrm{C} / \mathrm{yr}$ (Table 1 ), representing a subordinate but substantial component of the ecosystem carbon balance.

The ecohydrology group of HydroKorea and CarboKorea projects has proposed a major scientific question: What is the role of hydrology in the carbon budget of complex forest catchment and how will it change in the hydrologic cycle in monsoon Asia and influence the forest carbon budget? (Kim et al., 2006) To properly answer this question, some of the most fundamental aspects in catchment hydrology need to be clarified i.e., (1) How much water is stored in the catchments? (2) What flowpaths does water take to the stream? (3) How long does water reside in catchments? (4) How can we scale or transfer our observations to other catchments? Despite decades of dedicated scientific efforts on these fundamental questions, it is still difficult to find a robust interpretation even for some basic hydrological processes such as discharge and runoff. The up to date results showed that the geophysical and meteorological conditions greatly affect the hydrological processes (Hooper et al., 1990; Elsenber et al., 1995; Katsuyama et al., 2001; McGlynn and McDonnell, 2003).

There have been few studies that involve intensive ecohydrological measurements for the comprehensive understanding of hydrological processes and their effect on carbon cycling in Korean forest catchment. Therefore, we have implemented a comprehensive ecohydrological measurement system at the Gwangneung Supersite in Korea. Most importantly, high quality longterm data of hydrological and meteorological conditions have been collected, which may be also important in monitoring global environmental changes and their effects. The study was also designed based on a nested watershed concept (smaller catchments are nested in successively larger catchments) to investigate how catchment processes change as scale varies. A more detailed description of the study site and the experiment design in the Gwangneung Supersite can be found in Lee et al. (this issue). In this paper, we introduce the concepts and techniques that were implemented to investigate the movement of water and carbon in a forest catchment. We also briefly discuss preliminary results and their implications for the interactions between hydrological and biogeochemical processes in a catchment.

\section{DYNAMICS OF WATER IN FOREST SOILS}

The dynamics of water in the soil layer are important for the understanding of water storage and dissolved material fluxes in a forest catchment. In the Gwangneung catchment, an intensive monitoring is being conducted using a precise multiplex Time Domain Reflectometry system to capture and characterize variation patterns of soil moisture on a steep hillslope (Kim et al., 2007). Here, we introduce the methods for estimating the water and dissolved material flux in soils with tensiometer and water table fluctuations.

\subsection{Estimation of soil water and dissolved material flux using a tensiometer}

Tensiometer consists of a pressure transducer which measures the pressure (when saturated) or tension (when unsaturated) that the soil moisture exerts on a column of water, a porous cup which is in contact with the soil water at the measurement level, and a water body with a PVC pipe. According to Kim (2003), the one-dimensional, vertical water flow equation for unsaturated soil in a compartment can be written as :

$$
Q_{\text {in }}=Q_{\text {out }}-E+\Delta W
$$

where $Q_{\text {in }}$ and $Q_{\text {out }}$ are input and output of water to and from the compartment, respectively, $E$ is the evapo- 
transpiration, and $\Delta W$ is the change of water content in the compartment during the period. For example, $Q_{i n}$ in the $0-10 \mathrm{~m}$ soil compartment can be obtained from the throughfall measurement, and $\Delta W, E$ by direct observations. The calculated $Q_{o u t}$, in turn, becomes $Q_{\text {in }}$ for the 0.1-0.2 $\mathrm{m}$ soil compartment. Therefore, the equation can be used to calculate the water flux through a series of compartments up to $1.0 \mathrm{~m}$ soil depth.

$E$ can be calculated from temporal variations of evapotranspiration (Suzuki, 1980).

$$
E_{d 1-d 2}=c E
$$

where $E_{d 1-d 2}$ is the evapotranspiration at soil depth from $d 1$ to $d 2, E$ is the total evapotranspiration from the entire soil column, and $c$ is the proportion of $E_{d 1-d 2}$ to $E$. For example, $c$ in the $0-0.1 \mathrm{~m}$ soil compartment (if the total soil depth is $1.0 \mathrm{~m}$ ) during time $t$ is calculated from the change of water content by using equation (3).

$$
\begin{gathered}
c=\frac{\left(\theta_{0-10}^{t-\Delta t}-\theta_{0-10}^{t}\right)}{\left(\theta_{0-10}^{t+\Delta t}-\theta_{0-10}^{t}\right)+\left(\theta_{10-20}^{t-\Delta t}-\theta_{10-20}^{t}\right)+\left(\theta_{20-30}^{t+\Delta t}-\theta_{20-30}^{t}\right)} \\
\frac{\left(\theta_{0-10}^{t-\Delta t}-\theta_{0-10}^{t}\right)}{\left(\theta_{30-50}^{t+\Delta t}-\theta_{30-50}^{t}\right)+\left(\theta_{50-100}^{t+\Delta t}+\theta_{50-100}^{t}\right)}
\end{gathered}
$$

$\Delta W$ can be calculated from the change of water content, which is derived from the relationship between $\theta$ and $\psi$ (Kosugi, 1994; Kosugi, 1996).

$$
\Delta W=\left(\theta_{(d 1+d 2) / 2}^{t+\Delta t}-\theta_{(d 1+d 2) / 2}^{t}\right) \cdot Z
$$

where $\theta_{d}^{t}$ is the water content during time $t$ at soil depth $(d 1+d 2) / 2$, and $Z$ is the soil thickness.

Dissolved ions and compounds in soils move with water infiltration processes. Therefore, dissolved material flux is calculated by multiplying dissolved material

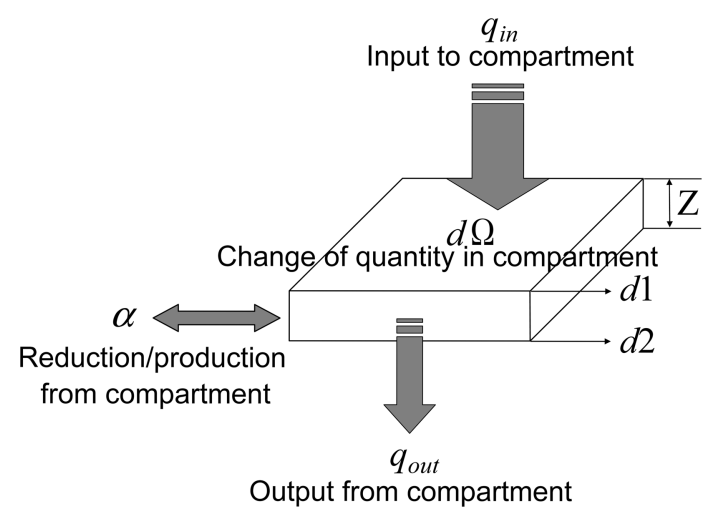

Fig. 1. Schematic calculation of dissolved material flux in soil compartment. concentration with the water flux. The calculation method of dissolved material flux is described in Fig. 1. The dissolved material flux is calculated from the change of quantity in a compartment. The sink/source $(\alpha)$ property of the compartment can be estimated from $q_{i n}, q_{\text {out }}$ and the change of quantity in the compartment $(d \Omega)$, such as:

$$
\alpha=d \Omega-\left(q_{\text {in }}-q_{\text {out }}\right)
$$

where $d \Omega$ is calculated from the concentration of dissolved materials and water content.

$$
d \Omega=\left(\theta_{(d 1+d 2) / 2}^{t+\Delta t} \cdot S_{(d 1+d 2) / 2}^{t+\Delta t}-\theta_{(d 1+d 2) / 2}^{t} \cdot S_{(d 1+d 2) / 2}^{t}\right) / Z
$$

where $S_{(d 1+d 2) / 2}^{t}$ is the dissolved material concentration during time $t$ at soil depth $(d l+d 2) / 2$. The equation (6) indicates the change of dissolved material budget in the soil compartment during time $t$. Moreover, $q_{\text {in }}$ and $q_{\text {out }}$ at depth $d$ can be described as:

$$
\begin{aligned}
& q_{\text {in }}=\left(f_{d 1}^{t}+f_{d 1}^{t+\Delta t}\right) / 2 \cdot \Delta t \\
& q_{\text {out }}=\left(f_{d 2}^{t}+f_{d 2}^{t+\Delta t}\right) / 2 \cdot \Delta t
\end{aligned}
$$

where $f_{d 1}^{t}$ is dissolved material flux at soil depth $d 1$ during time $t$.

\subsection{Estimation of water infiltration rate using a water table fluctuation}

The water infiltration rate can be calculated indirectly from the groundwater recharge rate. To estimate the water infiltration rate, the groundwater recharge rate from the water table fluctuation can be calculated as follows (Moon et al., 2004):

$$
\alpha=\frac{\sum h}{\sum p} \times S_{y}
$$

where $\alpha$ is the recharge rate, $h$ is the change of groundwater level, $P$ is precipitation, and $S_{y}$ is the specific yield. On specific conditions, groundwater recharge rate may practically represent the infiltration rate. We can also estimate the dissolved material flux, such as dissolved organic carbon (DOC) by multiplying groundwater recharge rate with the measured concentration.

This technique has been applied to the headwater region in the Gwangneung catchment, and its reliability has been critically evaluated by comparing with other methodologies. The uncertainty of this technique is largely due to the measurement error of specific yield 
$\left(S_{\mathrm{y}}\right)$ caused by the heterogeneity of geologic materials, and other factors influencing the water table fluctuation such as changes in atmospheric pressures, air entrapment during the infiltration of water, irrigation, and pumping (Choi et al., this issue).

\section{HYDROLOGICAL PROCESSES AND THE MEAN RESIDENCE TIME OF WATER IN A FOREST CATCHMENT}

Understanding the hydrological processes that control the movement of water in a forest catchment, in most cases, cannot be simply derived from physical characteristics. The physical information in hydrometric measurements provides insight on boundary conditions for hydrological systems, but they have limited utility in determining the residence time of water or specific flow pathways. In this section, we introduce the methods to estimate hydrological flowpaths during storm events and the mean residence time of water using hydro-biogeochemical approaches.

\subsection{Understanding of flowpaths using a hydro- graph separation}

Runoff may be separated into three components: surface runoff, interflow and groundwater runoff. The solute concentrations in each component may differ significantly depending on the runoff sources. Therefore, an accurate observation of the temporal changes in chemical composition of streamwater is fundamental to understand the runoff generating processes.

The characterization of flowpaths in forested catchments has been elusive because of the difficulties in measuring subsurface flow. Forested catchments are spatially complex and the subsurface flow is invisible. Hence, one can only infer the movement and mixing of water with the help of natural tracer elements that they carry (Pinder and Jones, 1969). Using various tracers, end-member mixing analysis (EMMA) has been widely conducted to elucidate pathways and relevant hydrological processes in a number of catchments (e.g. Hooper et al., 1990; Christophersen et al., 1990; Elsenbeer et al., 1995; Katsuyama et al., 2001).

The EMMA can be applied for individual storm events to quantitatively evaluate the contribution of each solutions component. The source waters are called 'end members'. The tracer concentrations of end members are more extreme than stream water since stream

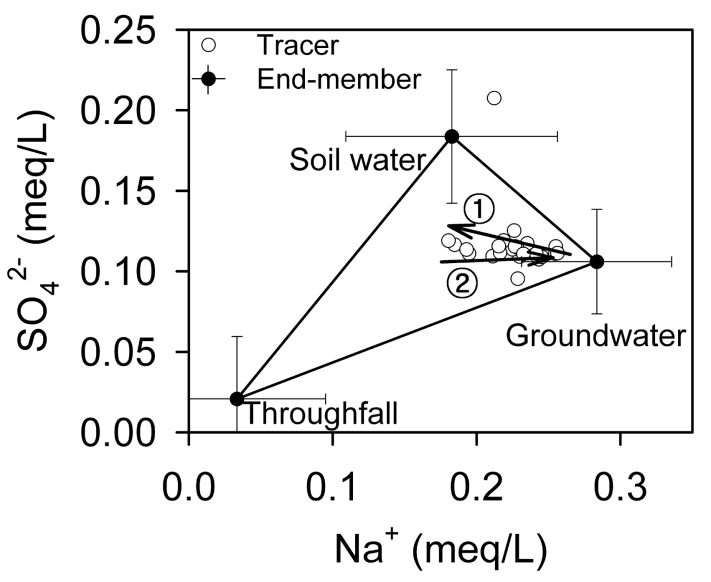

Fig. 2. Three-component mixing diagram for storm event. Stormflow solutes must lie within triangle defined by end members. (1) Stormflow solutes lay near the groundwater end-member, and moved to soil water. (2) Stormflow solutes closer to groundwater from soil water.

water is a mixture of these sources (Fig. 2). In order to apply EMMA, (1) tracers should be conservative, (2) sources should be significantly different in tracer concentrations, (3) unmeasured sources must have same concentration with known sources or don't contribute significantly, and (4) the sources should maintain a constant concentration. Typical source waters are those from organic rich soil horizon, hillslope groundwater, valley bottom groundwater, throughfall, and precipitation.

Here we introduce the application of EMMA in the Gwangneung catchment during storm events. The concentrations of $\mathrm{SO}_{4}{ }^{2-}$ and $\mathrm{Na}^{+}$were selected for the analysis because this combination provides the best separation of sources (Katsuyama et al., 2001). For the period from April to October 2005, Fig. 3 shows the mean and variations in the concentrations of $\mathrm{SO}_{4}{ }^{2-}$ and $\mathrm{Na}^{+}$of throughfall, soil water, shallow groundwater $(0.5 \mathrm{~m})$, deep groundwater $(0.8-1.0 \mathrm{~m})$, spring water, baseflow, and stormflow measured in this study. Average concentrations of $\mathrm{SO}_{4}{ }^{2-}$ and $\mathrm{Na}^{+}$were highest in soil water and deep groundwater, respectively. The shallow and the deep groundwater were not different significantly in the concentrations of these solutes (Fig. 3 ). Therefore, the deep groundwater could be treated as the first end-member of streamwater because $\mathrm{Na}^{+}$concentrations were highest possibly due to the accumulated effect of geochemical weathering. The throughfall can be treated as the second end-member because it is 

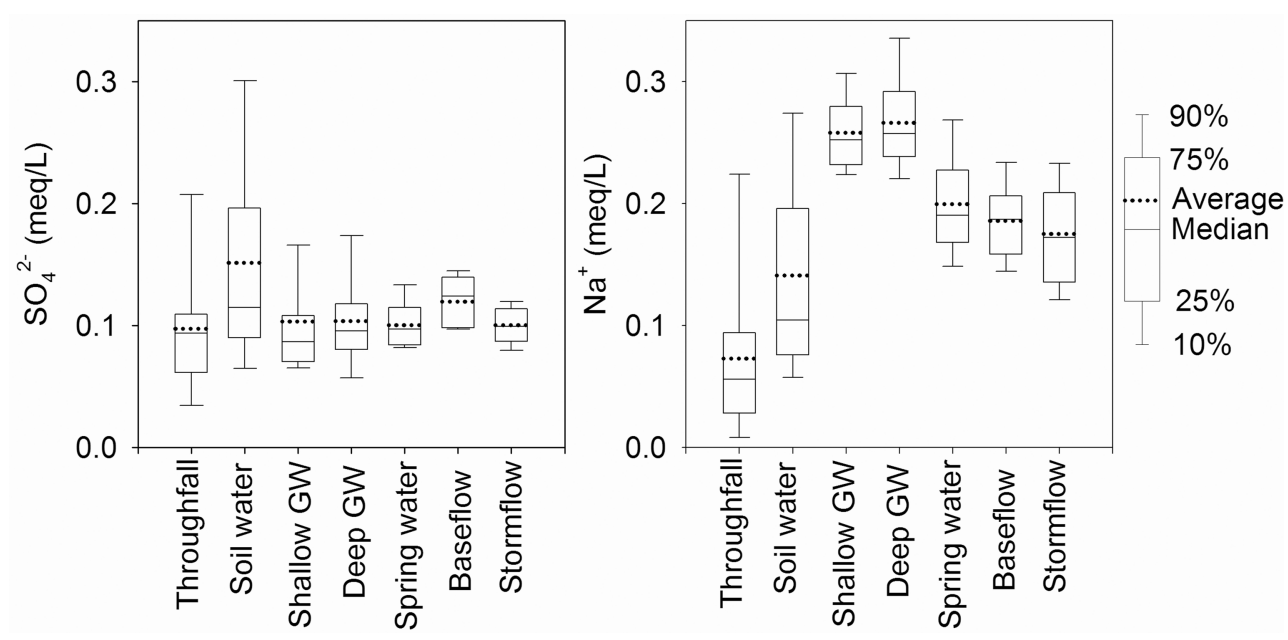

Fig. 3. Spatial variations in the concentrations of $\mathrm{SO}_{4}{ }^{2-}$ and $\mathrm{Na}^{+}$in throughfall, soil water, shallow groundwater $(0.5 \mathrm{~m})$, deep groundwater $(0.8-1.0 \mathrm{~m})$, spring water, and baseflow, with respect to stormflow.

the juvenile component without being affected by catchment biogeochemical processes and is mixed directly into the streamwater. The precipitation reached on the forest floor infiltrates and flows downstream. Hence, we can select the soil water as the third endmember.

The contribution of each end-member was calculated

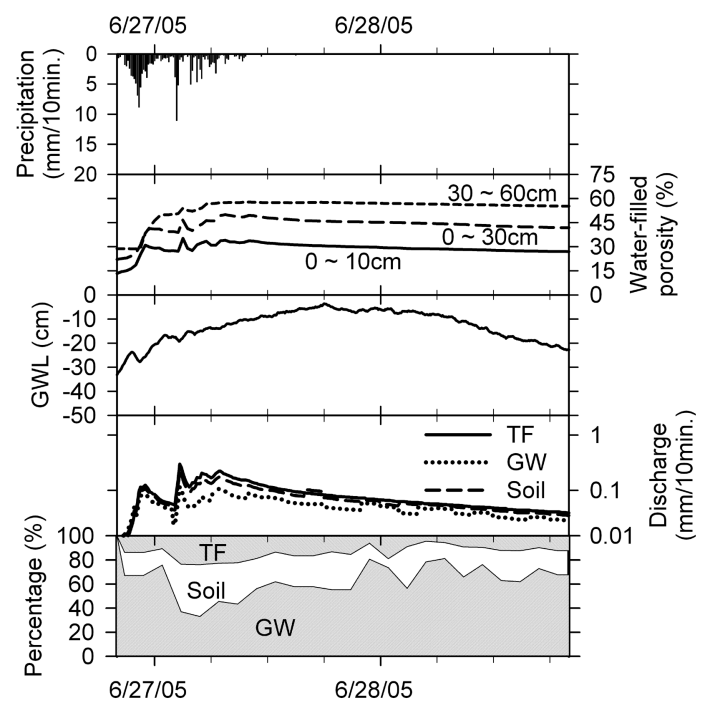

Fig. 4. Temporal variations in precipitation, water-filled porosity, groundwater level (GWL), hydrographic separation and contribution ratio of throughfall, soil water, and groundwater to stormflow during storm events. TF, GW, and Soil in the figure mean throughfall, groundwater, and soil water, respectively. by solving the following mass balance equations simultaneously (Hooper et al., 1990; Katsuyama et al., 2001):

$$
\begin{aligned}
& f_{a}+f_{b}+f_{c}=1 \\
& {\left[\mathrm{SO}_{4}{ }^{2-}\right]_{a} f_{a}+\left[\mathrm{SO}_{4}{ }^{2-}\right]_{b} f_{b}+\left[\mathrm{SO}_{4}{ }^{2-}\right]_{c} f_{c}=\left[\mathrm{SO}_{4}{ }^{2-}\right]_{s t}} \\
& {\left[\mathrm{Na}^{+}\right]_{a} f_{a}+\left[\mathrm{Na}^{+}\right]_{b} f_{b}+\left[\mathrm{Na}^{+}\right]_{c} f_{c}=\left[\mathrm{Na}^{+}\right]_{s t}}
\end{aligned}
$$

where subscripts $a, b$, and $c$ refer to the three different flowpaths; the subscript $s t$ refers to stream samples; $f$ refers to the fraction of stream discharge contributed by each flowpath; and $\left[\mathrm{SO}_{4}{ }^{2-}\right]$ and $\left[\mathrm{Na}^{+}\right]$refer to the concentrations of each ion.

Fig. 4 shows precipitation, water-filled porosity, groundwater level, and stream discharge for a storm event. As expected, the water-filled porosity in the shallow soil layer increased more quickly and to a greater extent than in the deeper soil layer. The groundwater level at R1-G4 immediately responded to the precipitation. In E050626, the groundwater level in the beginning was $0.3 \mathrm{~m}$ below the surface, which gradually increased to the subsurface and then decreased.

\subsection{Time lags between precipitation and other hydrological components during storm events}

We can quantify the time lag between the precipitation and the stream discharge or the soil moisture by calculating the cross correlation $\left(C_{A B}\right)$, which measures the persistence of two signals ( $A$ and $B$ ) during the measurement period and is defined as 


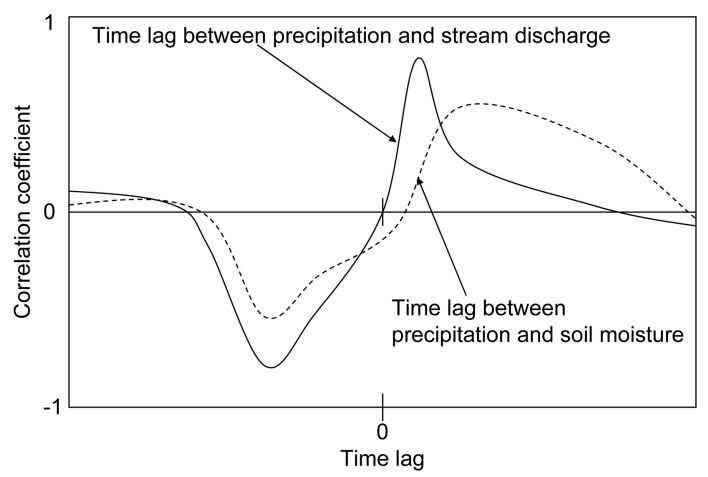

Fig. 5. Simulated cross correlation analysis among stream discharge, precipitation, and soil moisture.

(Stull, 1988):

$$
C_{A B}(L)=\frac{\sum_{k=0}^{N-j-1}\left[\left(A_{k}-\overline{A_{k}}\right)\left(B_{k+j}-\overline{B_{k+j}}\right)\right]}{\left[\sum_{k=0}^{N-j-1}\left(A_{k}-\bar{A}_{k}\right)\right]^{1 / 2}\left[\sum_{k=0}^{N-j-1}\left(B_{k}-\bar{B}_{k+j}\right)^{2}\right]^{1 / 2}}
$$

where $L$ is the time lag $(=j \Delta t), \Delta t$ is the measurement interval,

$$
\overline{A_{k}}=\frac{1}{N-j} \sum_{k=0}^{N-j-1} A_{k} \text { and } \overline{B_{k+j}}=\frac{1}{N-j} \sum_{k=0}^{N-j-1} B_{k+j} .
$$

Fig. 5 shows the time lags simulated from the cross correlation analysis among stream discharge, precipitation, and soil moisture. If the time lag between precipitation and soil moisture was longer than the time lag between precipitation and stream discharge, we can presume that the surface runoff occurred by the high precipitation intensity. This phenomenon occurs when the rate of precipitation on a surface exceeds the rate at which water infiltrates the ground, and any depression storage has already been filled. This is called the Hortonian overland flow (Horton, 1933). This occurs more commonly in arid and semi-arid regions where rainfall intensities are high and the soil infiltration capacity is reduced because of surface sealing, or in paved areas. When the soil is saturated and the depression storage is filled, the precipitation will immediately generate surface runoff, which is called saturated overland flow. In the Gwangneung catchment, the saturated overland flow was commonly observed especially during summer monsoon.

\subsection{Residence time of water in a forest catchment} Various radioactive tracers have provided valuable information regarding hydrological processes, such as mean residence time of water, flowpaths during storm events, groundwater movement, and biogeochemical reactions occurring along the flowpaths (Michel and Naftz, 1995; Shanley et al., 1998; Sueker et al., 1999). For example, ${ }^{3} \mathrm{H}$ and ${ }^{14} \mathrm{C}$ have been widely used for determination of time scale of hydrological processes (Matsutani et al., 1993). However, these tracers are inadequate for studying hydrological processes in small and headwater catchments with expected time scales of a year or less because of their long half lives (decades to thousands of years). In this study, we will introduce a short-lived cosmogenic radioactive isotope of ${ }^{35} \mathrm{~S}$ (half life $=87$ days) for measuring the mean residence time of water in the Gwangneung catchment.

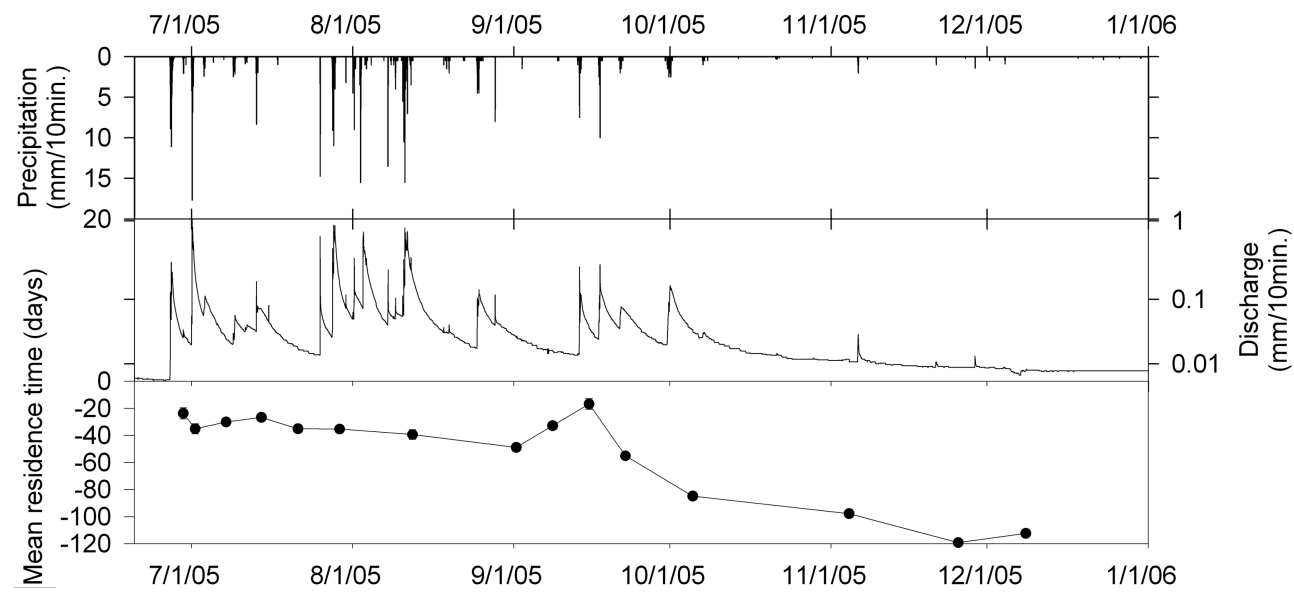

Fig. 6. Mean residence time of ${ }^{35} \mathrm{~S}$ in Gwangneung forest catchment. 
The measured activity of ${ }^{35} \mathrm{~S}$ in water can be expressed as an equation:

$$
C=C_{o} e^{-\lambda t}
$$

where $C_{o}$ is the initial ${ }^{35} \mathrm{~S}$ activity, $\lambda$ is the decay constant (0.0079655), $t$ is the number of days from the start of decay, and $C$ is the measured ${ }^{35} \mathrm{~S}$ activity.

The ${ }^{35} \mathrm{~S}$ activity in water provided information of the residence time of atmospherically deposited sulfate. Biogeochemical reactions such as adsorption/desorption in soil and groundwater are also important in affecting the calculated residence time of water in a forested catchment. Assuming a conservative response of sulfate in streamwater, the mean residence time of water was $<40$ days during the summer monsoon period in the Gwangneung catchment. However, the mean residence time of water increased to around 100 days in the dry season with increasing contribution of the base flow to the stream water (Fig. 6). These results demonstrate that ${ }^{35} \mathrm{~S}$ is useful in estimating the age of water exiting a small catchment where the time scales of hydrologic processes are on the order of 1 year or less.

\section{EFFECTS OF HYDRO-BIO- GEOCHEMICAL PROCESSES ON SOIL CARBON DYNAMICS IN A FOREST CATCHMENT}

Biotic/abiotic factors affect carbon production/consumption in forest soils (Kalbitz et al., 2000). One of the most important abiotic factors in soil carbon dynamics is the hydrological process. In this section, we review biogeochemical characteristics of forest soil carbon, and discuss the effects of hydrological processes on soil carbon dynamics based on the field data obtained from the Gwangneung forest catchment.

\subsection{Forms of carbon in soil-, ground-, and stream water, and biogeochemical reactions}

The main forms of carbon in stream water are particulated organic carbon (POC), dissolved organic carbon (DOC), and dissolved inorganic carbon (DIC). The distinction between DOC and POC is generally made on the basis of whether or not it passes through filters with 0.45-0.50 $\mu \mathrm{m}$ pore size (Herbert and Bertsch, 1995). Soil water contains varying amounts of DOC, which is originated from litter and other biomass. Since most of the DOC in soil water consists of complex and high molecular weight compounds, a general chemical definition of DOC is difficult to derive. Litterfall represents the most important source of DOC and POC inputs to the forest catchment. The turnover of DOC in soils is important as a major pathway of element cycling. DOC is also a major controlling factor in soil formation (Dawson et al., 1978; Kawasaki et al., 2005). POC concentration in stream water is more affected by the surface runoff in a forest catchment. The relationship between DOC concentration in stream water and hydrological processes will be discussed in following sections.

\subsection{Importance of DOC in soil carbon cycling}

DOC in soils plays important roles in the biogeochemical cycling of carbon, nitrogen, phosphorus, and other nutrients in aquatic ecosystems, and in the transport of pollutants in soils (Kalbitz et al., 2000; Perakis and Hedin, 2002).

The conceptual model for soil carbon cycling is described in Fig. 7. The soil carbon is divided into heavy and light fraction (Herbert and Bertsch, 1995). Most of the soil carbon is the heavy fraction, which includes microbes and refractory organic compounds (Guggenberger et al., 1994; Kalbitz et al., 2000). The rest of the soil carbon is the light fraction, which is mainly originated from the litterfall and consists of labile organic compounds (Guggenberger et al., 1994; Kalbitz et al., 2000). Therefore, light fraction is dominant in organic or humic layers. The proportion of dissolved form in soil carbon is relatively small $(<0.1 \%)$

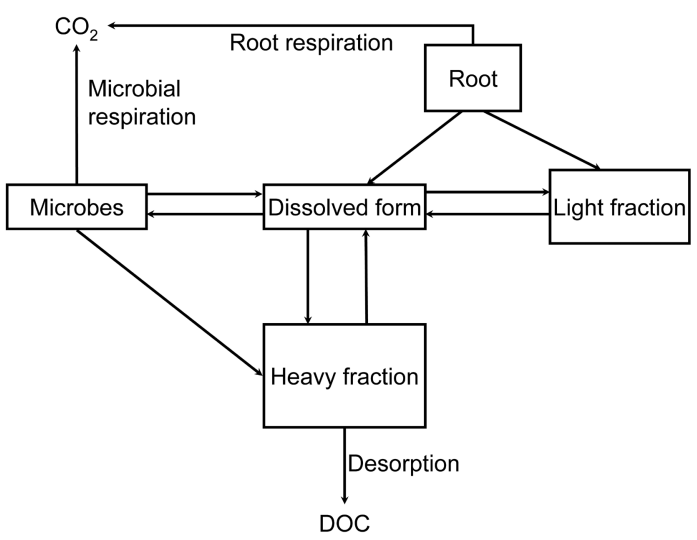

Fig. 7. Schematic model for soil organic carbon cycling: Relationship between dissolved organic carbon pool and other organic carbon pools. 
compared to the heavy and light fractions. However, heterotrophic microbes mostly metabolize dissolved forms as their energy source (Sato and Seto, 1999; Kalbitz et al., 2000; Wagai and Sollins, 2002). Dissolved form of carbon is used for cell formation, for microbial respiration, for desorption/adsorption, and for sedimentation from soil (Kalbitz et al., 2000). The dissolved form is preserved in small quantities as a result of the balance among the dissolution of soil organic matter, the consumption by microbes, and the absorption/desorption to/from minerals. Therefore, the mass balance of DOC can be an important indicator for soil biogeochemical processes.

\subsection{Adsorption of DOC in forest soil}

Many field studies have shown that the concentration of DOC in soil water significantly decreases with increasing soil depth (Fig. 8). It is generally assumed that adsorption of DOC to the surface of mineral soil is important than decomposition in reducing DOC concentrations. Various sorption mechanisms have been reported, including anion exchange, cation bridging, physical adsorption, etc. (Jardine et al., 1989; Gu et al., 1994; Edwards et al., 1996; Kaiser and Zech, 1998a; Kaiser and Zech, 1998b). These DOC sorptions are irreversible under natural soil conditions ( $\mathrm{Gu}$ et al., 1994). Because Fe and $\mathrm{Al}$ oxides are the most important sources of variable charge in soils (Jardine et al., 1989; Moore et al., 1992; Kaiser and Zech, 1998a), DOC adsorption can be related quantitatively to the Fe and Al oxide contents of soils (Moore et al., 1992). The proportion of clay in mineral soil is also an important

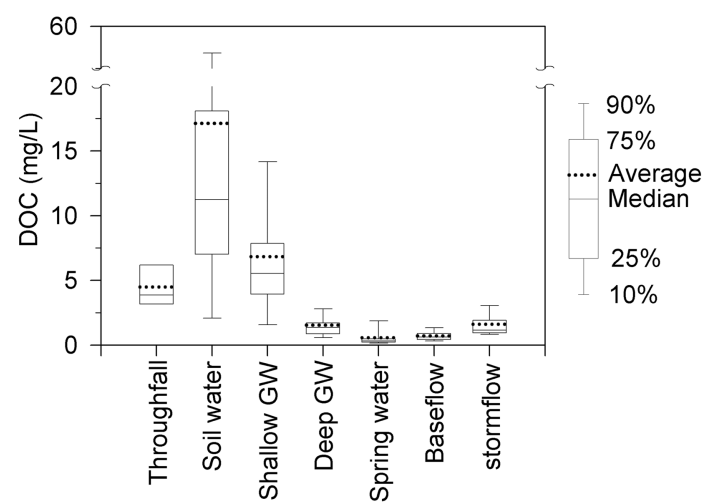

Fig. 8. Spatial variations in the concentrations of DOC of throughfall, soil water, shallow groundwater $(0.5 \mathrm{~m})$, deep groundwater $(0.8-1.0 \mathrm{~m})$, spring water, and baseflow, with respect to and stormflow. factor for DOC adsorption. DOC concentrations in catchment runoff are negatively correlated with the clay contents of soils in the catchment. The adsorption process is relatively rapid, which completed within 2 to 12 hours (Kaiser and Zech, 1998b). The effect of pH on the adsorption of DOC in forest soil is also important. Tipping and Woof (1990) calculated that an increase in soil $\mathrm{pH}$ by 0.5 units would lead to an increase by about $50 \%$ in the amount of mobilized organic matter. Nodvin et al. (1986) also calculated the reactive soil pool of DOC under various $\mathrm{pH}$ conditions.

\subsection{DOC flux and accumulation in forest soils} Kawasaki et al. (2005) calculated the DOC flux and accumulation in forest soil by the multiplication of soil water flux and DOC concentration. They reported that DOC removal rate is $87 \%$ of the total incoming DOC flux to the surface mineral soil. As described above, this result correlates with DOC adsorption mechanisms.

Lim et al. (2003) estimated that the annual net primary productivity (NPP) in Gwangneung deciduous forest is about $4.3 \mathrm{t}-\mathrm{C} \mathrm{ha} \mathrm{hr}^{-1}$. The annual DOC discharge from Gwangneung deciduous forest catchment was estimated at about $0.04 \mathrm{t}-\mathrm{C} \mathrm{ha}{ }^{-1} \mathrm{yr}^{-1}$ (Kim and Kim, 2006). Such a small magnitude of DOC discharge necessitates estimations of retention and release of DOC within the soil. Based on the results from water infiltration rate, an average of $0.45 \mathrm{t}-\mathrm{C} \mathrm{ha}{ }^{-1}$ of DOC was infiltrated into the soil from late June to early October. These results indicate that $\sim 8 \%$ of the litterfall carbon (5.6 t-C ha ${ }^{-1}$; Lim et al., 2003) was stored in soil as DOC with water movement. If most of the infiltrated DOC was preserved and accumulated as soil organic carbon in the shallow soil, the $0.45 \mathrm{t}-\mathrm{C} \mathrm{ha}{ }^{-1}$ of DOC that corresponds to $\sim 0.5 \%$ of the total soil carbon $(92.0 \mathrm{t}-\mathrm{C}$ ha $^{-1}$; Lim et al., 2003) and $\sim 10 \%$ of the annual NPP would be retained during summer monsoon. Although these values are small, it should be noted that DOC is the most reactive component in the bulk soil organic carbon and therefore, its amount may change drastically depending on the climatic and hydrological conditions. Therefore, this $0.5 \%$ of soil carbon retained as DOC can be considered as an important component of the carbon budget in forest ecosystems.

\subsection{Temporal change of DOC concentration in streamwater during storm events}

Typical temporal variations in DOC concentrations 


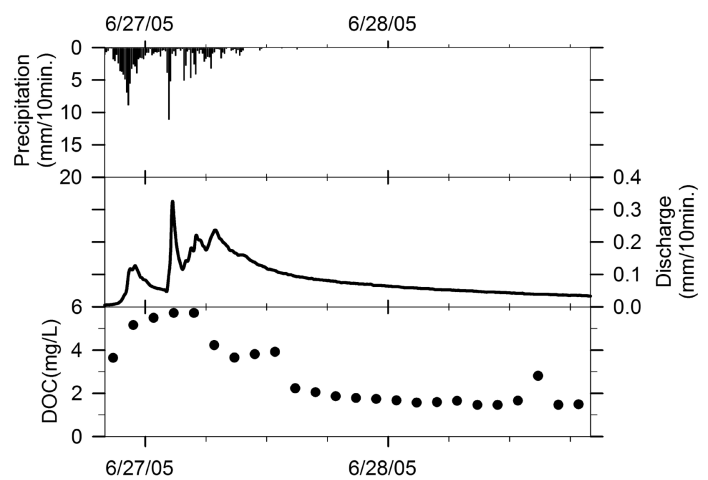

Fig. 9. Precipitation, stream discharge and temporal variations of DOC concentration in streamwater during storm event.

during storm events are shown in Fig. 9. With the onset of heavy precipitation, DOC concentration in streamwater increases significantly, and after the precipitation ceased, DOC concentrations returned to pre-storm levels. The results from the hydrograph separation during storm events indicated that a large amount of water discharged through surface and subsurface soil layers (Fig. 4). DOC concentration in the surface soil is higher than the deep soil and the groundwater (Fig. 8). The Storm event leads to the increase in the surface runoff with a high DOC concentration. During the baseflow period, most stream waters flow out from the groundwater with a low DOC concentration (Fig. 10). These results indicate that hydrological processes strongly affect the DOC export and thereby the carbon budget in the catchment.

Storm event period; Large supply from surface soil

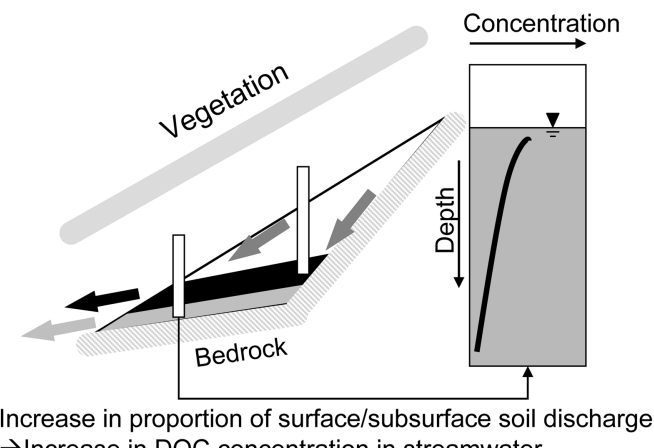

$\rightarrow$ Increase in DOC concentration in streamwater

\section{SUMMARY AND OUTLOOK}

The seasonally concentrated precipitation increases the surface runoff, when the infiltration capacity of the soil decreases during summer monsoon. The outbreak of surface runoff reduced the mean residence time of water in the catchment, and increased DOC export from the surface soil layer. The precipitation also plays an important role in infiltration processes of dissolved material. The precipitation patterns and hydrological processes strongly affect the carbon cycling in the Korean temperate forest during summer monsoon. The increasing occasions of heavy precipitation may not lead to the simultaneous increase of available water resources in the catchment due to the shortening of the water residence time. However, the heavy precipitation will clearly increase material discharge such as DOC. Therefore, the effect of monsoon climate on water and carbon cycling in forest catchment should be critically evaluated on the basis of improved understanding of catchment hydrological and biogechemical processes.

The major interest in HydroKorea and CarboKorea is the generalization of water and carbon flowpaths, storage, residence time, and scaling. Our understandings in water and carbon cycling obtained from the hydro-biogeochemical approaches are limited due to the prescribed spatial scale of the measurements (Moon et al., this issue). The scaling issues are implicitly built into our field measurements and model representations (Kim et al., 2006). The data presented in our study are currently used to calibrate and improve ecohydrologi-
Base flow period;

Small supply from surface soil

Fig. 10. Schematic model for determining the DOC concentrations in streamwater. Modified from Kim et al. (2003). 
cal modeling schemes such as the Regional Hydrological and Ecological Simulation System (RHESSys) (see Kim et al. this issue), which will be used to estimate long-term and large-scale exchanges of water and carbon in Korean forest catchments.

\section{적 요}

한국 산악 경관에서의 물과 탄소의 순환을 이해하고 예측하기 위해서는 물과 탄소의 유역 내 이동 경로, 저류, 체류시간 및 상호작용에 대한 정보가 선행되어야 한다. 이와 관련하여 본 논문에서는 HydroKorea 및 CarboKorea 연구에서 사용하고 있는 연구 방법들과 현재까지의 주요 결과를 소개한다. 유역 내 다양한 수 문순환 과정을 이해하기 위해 지하수위 변동, endmember mixing model, 교차상관 분석, 대기 기원의 천연방사성 동위원소를 이용하였다. 광릉 산림 유역에 서는 지표유출의 기여도가 상대적으로 높았고, 강수량 과 강수강도 및 패턴의 변화가 물의 유출경로와 체류 시간에 영향을 주었다. 특히, 몬순으로 인한 강수형태 와 유역 내 수문과정의 변화가 탄소 순환에 영향을 미쳤는데, 지속적인 강우의 유입이 산림토양의 표층에 분포하는 고농도의 용존유기탄소의 유출을 증가시켰다. 본 연구를 통하여 시도된 수문순환과정에 대한 정량적 인 규명은 기후 변화가 수자원 관리와 산림유역 탄소 순환에 미치는 영향을 예측하기 위한 과학적 방법론을 확립하는데 기여할 것으로 기대된다.

\section{ACKNOWLEDGEMENTS}

This research was supported by grants (code: 1-8-2) from Sustainable Water Resources Research Center for 21st Century Frontier Research Program, the EcoTechnopia 21 Project of the Ministry of Environment, and BK21 Program of the Ministry of Education and Human Resources Development of Korea. We also thank two anonymous reviewers for improvement of this manuscript.

\section{REFERENCES}

Anderson, M. G. and T. P. Burt, 1991: Process Studies in Hillslope Hydrology. John Wiley and Sons, 539pp.

Betson, R. P., 1964: What is watershed runoff? Journal of Geophysical Research 69, 1541-1551.

Choi, I. H., N. C. Woo, S. J. Kim, and J. Kim, 2007: Estimation of the groundwater recharge rate at a headwater catchment in Gwangneung, Korea. Korean Journal of
Agricultural and Forestry Meteorology, this issue.

Christophersen, N., C. Neal, R. P. Hooper, R. D. Vogt, and S. Andersen, 1990: Modeling streamwater chemistry as a mixture of soilwater end-members - a step towards second-generation acidification models. Journal of Hydrology 116, 307-320.

Dawson, H. J., F. C. Ugolini, B. F. Hrutfiord, and J. Zachara, 1975: Role of soluble organics in the soil processes of a podzol, Central Cascades, Washington. Soil Science 126, 290-296.

Edwards, M., M. M. Bejamin, and J. N. Ryan, 1996: Role of organic acidity in sorption of natural organic matter (NOM) to oxide surfaces. Colloid Surfaces A 107, 297307.

Elsenbeer, H., D. Lorieri, and M. Bonell, 1995: Mixing model approaches to estimate storm flow sources in an overland flow-dominated tropical rain forest catchment. Water Resources Research 31, 2267-2278.

Gu, B., J. Schimitt, Z. Chen, L. Liang, and J. F. McCarthy, 1994: Adsorption and desorption of natural organic matter on iron oxides: Mechanisms and models. Environmental Science \& Technology 28, 38-46.

Guggenberger, G., W. Zech, and H. -R., Schulten, 1994: Formation and mobilization pathways of dissolved organic matter: evidence from chemical structural studies of organic matter fractions in acid forest floor solutions. Organic Geochemistry 21(1), 51-66.

Herbert, B. E., and P. M. Bertsch, 1995: Characterization of dissolved and colloidal organic matter in soil solution. Carbon forms and functions in forest soils, J. M. Kelly and W. W. McFee (Eds), SSSA, Madison, WI, 6388.

Hooper, R. P., N. Christophersen, and N. E. Peters, 1990: Modeling streamwater chemistry as a mixture of soilwater end-members-an application to the Panola Mountain Catchment, Georgia, U.S.A. Journal of Hydrology 116, 321-343.

Horton, R. E., 1933: The role of infiltration in the hydrologic cycle. American Geophysical Union. Transaction 14, 446-460.

Jardine, P. M., N. L. Weber, and J. F. McCarthy, 1989: Mechanism of dissolved organic carbon adsorption on soil. Soil Science Society of America Journal 53, 13781385.

Kaiser, K., and W. Zech, 1998a: Soil dissolved organic matter sorption as influenced by organic and sesquioxide coatings and sorbed sulfate. Soil Science Society of America Journal 62, 129-136.

Kaiser, K., and W. Zech, 1998b: Rates of dissolved organic matter release and sorption in forest soils. Soil Science 62, 129-136.

Kalbitz, K., S. Solinger, J. -H. Park, B. Michalzik, and E. Matzner, 2000: Controls on the dynamics of dissolved organic matter in soils: a review. Soil Science 165, 277- 
304

Katsuyama, M., N. Ohte, and S. Kobashi, 2001: A threecomponent end-member analysis of streamwater hydrochemistry in a small Japanese forested headwater catchment. Hydrological Processes 15, 249-260.

Kawasaki, M., N. Ohte, and M. Katsuyama, 2005: Biogeochemical and hydrological controls on carbon export from a forested catchment in central Japan. Ecological Research 20, 347-358.

Kim, E., S. Kang, B. Lee, K. Kim, and J. Kim, 2007: Application and parameterization of RHESSys for integrating the eco-hydrological processes in the Gwangneung small watershed. Korean Journal of Agricultural and Forestry Meteorology, this issue.

Kim, S. J., 2003: Hydro-Biogeochemical Study on the Sulfur Dynamics in a Temperature Forest Catchment. Ph. D. Dissertation. Kyoto University.

Kim, S. J., N. Ohte., M. Kawasaki., M. Katsuyama., N. Tokuchi, and S. Hobara, 2003: Interactive responses of dissolved sulfate and nitrate to disturbance associated with pine wilt disease in a temperate forest. Soil Science and Plant Nutrition 49, 539-550.

Kim, S. J., and J. Kim, 2006: How to evaluate the DOC and POC discharge from forest ecosystem during monsoon? USA PUB Workshop, CUASHI.

Kim, S., H. Lee, N. C. Woo, and J. Kim, 2007: Soil moisture monitoring in a steep relief. Hydrological Processes, in press, $10.1002 / \mathrm{hyp} .6508$.

Kim, J., D. Lee, J. Hong, S. Kang, S. J. Kim, S. K. Moon, H. H. Lim, Y. Son, J. Lee, S. Kim, N. Woo, K. Kim, B. Lee, B. L. Lee, and S. Kim, 2006: HydroKorea and CarboKorea: cross-scale studies of ecohydrology and biogeochemistry in a heterogeneous and complex forest catchment of Korea. Ecological Research 21, 881-889.

Kirkby, M.J., 1978: Hillslope Hydrology. John Wiley and Sons, 389pp.

Kosugi, K., 1994: Three-parameter lognormal distribution model for soil water retain. Water Resources Research 30, 891-901.

Kosugi, K., 1996: Lognormal distribution model of unsaturated soil hydraulic properties. Water Resources Research 32, 2697-2703.

Lim, J. H., J. H. Shin, G. Z. Jin, J. H. Chun, and J. S. Oh, 2003: Forest stand structure, site characteristics and carbon budget of the Kwangneung natural forest in Korea. Korean Journal of Agricultural and Forestry Meteorology 5, 101-109.

Ludwig, W., J. L. Probst, and S. Kempe, 1996: Predicting the oceanic input of organic carbon by continental erosion. Global Biogeochemical Cycles 10, 23-41.

Matsutani, J., T. Tanaka, and M. Tsujimura, 1993: Residence times of soil, ground, and discharge waters in a mountainous headwater basin, central Japan, traced by tritium. Tracers in Hydrology, N. E. Peters, E. Hoehn,
Ch. Leibundgut, N. Tase., and D. E. Walling (Eds.), IAHS Publication No. 215, 57-64.

McGlynn, B. L., and J. J. McDonnell, 2003: Role of discrete landscape units in controlling catchment dissolved organic carbon dynamics. Water Resources Research 39(4), 1090, doi:10.1029/2002WR001525.

Meybeck, M., 1982: Carbon, nitrogen, and phosphorus transport by the world rivers. American Journal of Science 282, 401-450.

Michel, R. L., and D. L. Naftz, 1995: Use of sulfur-35 and tritium to study runoff from an alpine glacier, Wind River Range, Wyoming. Biogeochemistry of Seasonally Snow-Covered Catchments, K. A. Tonnessen, M. W. Williams, M., Tranter, (Eds.), International Association of Hydrological Sciences. Boulder, CO. Publication No. 228, 441-443.

Moon, S. -K., N. C. Woo, and K. S. Lee, 2004: Statistical analysis of hydrographs and water-table fluctuation to estimate groundwater recharge. Journal of Hydrology 292, 198-209, doi:10.1016/j.jhydrol.2003.12.030.

Moon, S. -K., Y. Ryu, D. Lee, and J. Kim, 2007: Quantifying the Spatial Heterogeneity of the Land Surface Parameters at the Two Contrasting KoFlux Sites by Semivariogram. Korean Journal of Agricultural and Forestry Meteorology, this issue.

Moore, T. R., W. Desouza, and J. F. Koprivnijak, 1992: Controls on the sorption of dissolved organic carbon in soils. Soil Science 154, 120-129.

Nodvin, S. C., C. T. Driscoll, and G. E. Likens, 1986: Simple partitioning of anions and dissolved organic carbon in a forest soil. Soil Science 142, 27-35.

Perakis, S. S., and L. O. Hedin, 2002: Nitrogen loss from unpolluted South American forest mainly via dissolved organic compounds. Science 415, 416-419.

Pinder, G. F., and J. F. Jones, 1969: Determination of the groundwater component of peak discharge from the chemistry of total runoff water. Water Resources Research 5(2), 438-445.

Prentice, I. C., G. D. Farquhar, M. J. R. Fasham, M. L. Goulden, M. Heimann, V. J. Jaramillo, H. S. Kheshgi, C. Le Quéré, R. J. Scholes, and D. W. R. Wallace, 2001: The carbon cycle and atmospheric carbon dioxide, in Climate Change 2001: The Scientific Basis. Contribution of Working Group I to the Third Assessment Report of the Intergovernmental Panel on Climate Change, J. T. Houghton, Y. Ding, D. J. Griggs, M. Noguer, P. J. van der Linden, X. Dai, K. Maskell, and C.A. Johnson (Eds), Cambridge University Press, 190pp.

Sato, A., and M. Seto, 1999: Relationship between rate of carbon dioxide evolution, microbial biomass carbon, and amount of dissolved organic carbon as affected by temperature and water content of a forest and an arable soil. Communications in Soil Science and Plant Analysis 30, 2593-2605. 
Schlesinger, W. H., and J. M. Melack 1981: Transport of organic carbon in the world's rivers. Tellus 33, 172-181.

Schulze, E.-D., 2006: Biological control of the terrestrial carbon sink. Biogeosciences 3, 147-166.

Shanley, J. B., E. Pendall, C. Kendall, L. R. Stevens, R. L. Nichel, P. J. Phillips, R. M. Forester, D. L. Naftz, B. Liu, L. Stern, B. B. Wolfe, C. P. Chamerlain, S. W. Leavitt, T. H. E. Heaton, B. Mayer, L. D. Cecil, W. B. Lyons, B. G. Katz, J. L. Betancourt, D. M. McKnight, J. D. Blum, T. W. D. Edwards, H. R. House, E. Ito, R. O. Aravena, and J. F. Whelan, 1998: Isotope as indicators of environmental change. Isotope tracers in catchment hydrology, C. Kendall and J. J. McDonnell (Eds.), Elsevier, 761-816.

Stull, R. B., 1988: An Introduction to Boundary Layer Meteorology. Kluwer Academic Publishers, 666 pp.

Sueker, J. K., J. T. Turk, and R. L. Michel, 1999: Use of cosmogenic ${ }^{35} \mathrm{~S}$ for comparing ages of water from three alpine-subalpine basins in the Colorado Front Range.
Geomorphology 27, 61-74.

Suzuki, M., 1980: Evapotranspiration from a small catchment in hilly mountain (I) Seasonal variations in evapotranspiration, rainfall interception and transpiration. Journal of Japanese Forest Society 62, 46-53.

Tipping, E., and C. Woof, 1990: Humic substances in acid organic soils: Modeling their release to the soil solution in terms of humic charge. Journal of Soil Science 41, 573-585.

Wagai, R., and P. Sollins, 2002: Biodegradation and regeneration of water-soluble organic carbon in a forest soil: leaching column study. Biology and Fertility of Soils 35, 18-26.

Warnken, K. W., and P. H. Santschi, 2004: Giogeochemical behavior of oganic carbon in the Trinity River downstream of a large reservoir lake in Texas, USA. Science of the Total Environment 329, 131-144. 